\title{
KEBIJAKAN TRANSPORTASI UMUM (ANGKOT) UNTUK MENANGGULANGI KEMACETAN JALAN
}

\author{
Junita Ayu Ariesandi, Reiza Resita, dan Zulfitri Salsabila \\ FISIP Universitas Muhammadiyah Malang, Jl. Raya Tlogomas, Malang
}

\begin{abstract}
Malang City continues to face congestion in the field of public transportation because the government is not taking it seriously. The cause of congestion by public transportation is because there are still careless stops when unloading passengers. The focus of this research is to identify and describe the factors that hamper the policy steps made and the efforts that have been made by the Malang City Government in overcoming congestion problems, especially those related to public transportation or public transportation (angkot). This study conducted a descriptive research method using a qualitative approach, where the data were obtained through literature study of previous research results and data obtained from news articles and documents that were in accordance with the research theme. The results of this study indicate that the policies that have been implemented by the City Government of Malang are a one-way lane system in the UB ring area which has been running smoothly, the imposition of oblique parking in several areas. On the other hand, the Mayor of Malang has designed a policy that focuses on public transportation (angkot) which will be application-based or online which was actually carried out on trial in April 2020, but this policy has not yet been realized because it is hampered by the current situation.
\end{abstract}

\begin{abstract}
Abstrak: Kota Malang terus dihadapi kemacetan di bidang transportasi publik karena tidak digarap dengan serius oleh pemerintah. Penyebab kemacetan oleh angkutan umum karena masih terjadinya pemberhentian sembarangan saat menurunkan penumpangnya. Fokus penelitian ini adalah untuk mengetahui dan mendeskripsikan faktor yang menjadi penghambat langkah kebijakan yang dibuat dan upaya yang sudah dilakukan Pemerintah Kota Malang dalam menanggulangi permasalahan kemacetan khususnya yang berkaitan dengan kendaraan umum atau transportasi publik (angkot). Penelitian ini melakukan metode penelitian deskriptif dengan menggunakan pendekatan kualitatif, dimana data yang didapatkan melalui studi pustaka hasil penelitian sebelumnya dan data yang diperoleh dari artikel berita dan dokumen-dokumen yang sesuai dengan tema penelitian. Hasil dari penelitian ini menunjukan bahwa kebijakan yang telah diterapkan Pemerintah Kota Malang adalah sistem jalur satu arah di kawasan lingkar UB yang sudah berjalan lancar, diberlakukannya parkir miring atau serong di beberapa kawasan. Di sisi lain Walikota Malang telah merancang kebijakan yang berfokus kepada angkutan umum (angkot) yang akan berbasis aplikasi atau daring yang sebenarnya dilaksanakan ujicoba pada April 2020, tetapi kebijakan ini masih belum terealisasikan karena terhambat oleh situasi saat ini.
\end{abstract}

Kata Kunci: kebijakan publik, transportasi umum, kemacetan, Pemkot Malang

\section{PENDAHULUAN}

Banyak kota besar di Indonesia saat ini dihadapkan oleh berbagai permasalahan terkait dengan pelayanan publik. Dimana permasalahan yang ada telah menjadi perhatian dan keprihatinan baik itu ditingkat pemerintahan daerah maupun pemerintahan pusat. Permasalahan tersebut diantaranya banjir, kepadatan penduduk, kemiskinan, tata ruang hingga masalah kemacetan. Namun kemacetan sekarang ini menjadi masalah utama di bidang transportasi publik. Seperti halnya yang dialami Kota Malang dimana melihat perkembangan kota ini yang cukup signifikan dengan predikat barunya sebagai kota ketiga yang memiliki tingkat kemacetan tertinggi di Indonesia.
Berdasarkan data BPS yang merujuk dari Kantor Samsat Bersama Kota Malang, jumlah kendaraan bermotor di Kota Malang terus mengalami kenaikan. Data 2012 menunjukkan bahwa jumlah kendaraan bermotor ada di angka 471.272 unit. Sedangkan pada 2017, jumlah kendaraan bermotor yang tercatat sebanyak 584.772 kendaraan. Artinya dalam kurun waktu lima tahun terdapat peningkatan sebanyak 113.500 unit kendaraan bermotor atau rata-rata 22.700 unit kendaraan per tahun. Permasalahan yang dihadapi ini bukan sebatas penyediaan sarana dan prasarana publik yang kurang memadai saja akan tetapi, penggunaan kendaraan pribadi yang tidak ada batasnya. Belum lagi apabila dilihat dari banyaknya permasalahan yang 
dialami pada berbagai kondisi sosial, ekonomi, dan budaya masyarakatnya yang membuat pola pikir masyarakat hanya untuk kepentingan pribadi.

Beberapa hal yang mempengaruhi timbulnya permasalahan kemacetan di Kota Malang, yaitu tingginya angka penggunaan kendaraan pribadi, dilihat dari gaya hidup masyarakat yang masih ekslusif merasa lebih nyaman menggunakan kendaraan pribadi dari pada kendaraan umum (publik). Selain itu, Kota Malang juga dikenal sebagai kota pendidikan dan kota destinasi wisata yang menyebabkan penambahan angka kemacetan. Sebagai kota pendidikan, kemacetan yang dialami didominasi oleh kendaraan para pelajar, mahasiswa dalam kota ataupun luar kota. Begitu pula dengan destinasi wisata yang mendatangkan para wisatawan dari luar daerah. Disamping itu yang menjadi penyebab kemacetan lainnya seperti tempat publik yang dijadikan tidak sebagaimana fungsinya oleh oknum-oknum tertentu sebagai parkiran liar. Hal itu nampak di depan atau samping pasar dan pusat perbelanjaan yang tidak menyediakan lahan parkir sehingga menggunakan badan jalan sebagai tempat parkir kendaraan.

Kemudian terbatasnya prasarana jalan dengan melihat jalanan Kota Malang yang sempit namun dilewati oleh banyak kendaraan juga, ditambah para sopir angkutan umum yang suka menaik turunkan penumpang secara sembarangan dan tidak sesuai tempat pemberhentian juga menjadi salah satu penyebab kemacetan. Para sopir kendaraan umum baik itu angkutan dalam kota (angkot) atau bus seringkali dalam mencari dan mengangkut penumpang tidak sesuai dengan kententuan yang tertera dalam Perda Kota Malang No 5 Tahun 2011 tentang Penyelenggaraan Angkutan Orang di Jalan dengan Kendaraan Bermotor Umum yaitu pada Bab IV mengenai Kewajiban Pengemudi Kendaraan Bermotor Umum untukAngkutan Orang Dalam Trayek Pasal 21 dan Pasal 22. Dimana pada Pasal 21 sopir kendaraan umum memiliki kewajiban dalam mematuhi ketentuan dibidang pelayanan dan keselamatan angkutan serta Pasal 22 yang memuat poin secara keseluruhan yang harus dipatuhi oleh setiap pengemudi kendaraan umum yang diantaranya (1) Setiap pengemudi kendaraan umum yang mengoperasikan mobil bus dan/atau mobil penumpang harus mematuhi tata cara menaikkan dan menurunkan penumpang serta tata cara pelayanan dan keselamatan angkutan umum; (2) Tata cara menaikkan dan menurunkan penumpang sebagaimana dimaksud pada ayat (1), diatur sebagai berikut: a. di terminal, sejak awal pemberangkatan, persinggahan, sampai tujuan dan tempat tempat lain yang ditentukan; b. menaikkan penumpang dari pintu depan dan menurunkan penumpang dari pintu belakang secara tertib dan teratur, kecuali yang tidak berpintu ganda; (3) Dalam menaikkan dan menurunkan penumpang sebagaimana dimaksud pada ayat (1), kendaraan harus dalam keadaan berhenti penuh dan tidak mengganggu kelancaran lalu lintas serta membahayakan penumpangnya. Sebagai kota besar yang dikenal sebagai kota pendidikan, dimana mayoritas mahasiswa Perguruan Tinggi berasal dari luar kota sehingga kebutuhan dalam menggunakan kendaraan umum dan pribadi cukuplah tinggi. Seharusnya pemerintah Kota Malang mampu menyediakan transportasi publik khususnya angkot dengan fasilitas yang baik dan halte untuk transportasi umum yang tidak hanya sebagai tempat pemberhentian bus saja serta menerapkan jam tertentu secara bergantian dan teratur agar kepadatan lalu lintas tidak cukup menumpuk di jam-jam tertentu karena minimnya fasilitas yang disediakan. Hal diatas bisa dijadikan sebagai salah satu alternative dalam perbaikan transportasi publik dengan menyediakan fasilitas pendukung bagi pengguna angkutan umum demi kenyamanan bersama khususnya pengguna layanan ataupun para pengguna jalan. Sebab disisi lain terkadang angkutan umum juga menjadi penyebab kemacetan karena banyaknya sopir angkutan umum yang secara sembarangan dalam menaik turunkan penumpangnya, berhenti di pinggir jalan ataupun berhenti mendadak dibadan jalan hingga ngetem diluar dekat saat mencari penumpang sehingga hal ini sangat perlu diberi perhatian khusus maupun sanksi tegas oleh aparat sebagai salah satu upaya penerapan kebijakan kendaraan umum yaitu Perda Kota Malang No 5 Tahun 2011 tentang Penyelenggaraan Ang- 
kutan Orang di Jalan dengan Kendaraan Bermotor Umum Pasal 21 dan Pasal 22.

Pentingnya sektor transportasi untuk kegiatan ekonomi membutuhkan sistem transportasi yang handal, efisien, dan efektif(Asmawi, 2017). Transportasi yang efektif berarti bahwa sistem transportasi memenuhi kapasitas angkut yang bersatu atau terintegrasi dengan moda transportasi lainnya secara tertib, teratur, lancar, cepat dan tepat, aman, nyaman dan ekonomis. Sementara efisien dalam arti beban publik sebagai pengguna jasa transportasi menjadi rendah dan memiliki kegunaan yang tinggi. Hal ini sesuai dengan tujuan diselenggarakannya transportasi jalan yaitu untuk menerapkan lalu lintas dan angkutan jalan dengan aman, lancar, tertib, nyaman dan efisien; mampu mengintegrasikan moda transportasi lainnya; menjangkau seluruh pelosok wilayah daratan, menunjang pemerataan, dan mendukung pembangunan nasional dengan biaya yang terjangkau oleh masyarakat (Wardana, 2019).

Kebijakan transportasi sebagai apa yang dinyatakan dan dilakukan atau tidak dilakukan oleh pemerintah. Kebijakan itu dapat berupa sasaran atau tujuan dari program-program pemerintah di bidang tranpostasi. Penetapan kebijakan dapat secara jelas diwujudkan dalam peraturan-peraturan perundang-undangan atau dalam pidato-pidato pejabat pemerintah serta program dan tindakan yang dilakukan oleh pemerintah. Dari definisi di atas bisa dilihat bahwa dalam mendefinisikan kebijakan publik memiliki kata kunci "tujuan", "nilai-nilai”, dan "praktik". Kebijakan publik dalam teori ini menilai selalu memiliki tujuan, seperti kebijakan yang akan diberikan pemerintah dalam mengurangi kemacetan. Dalam praktiknya ataupun pelaksanaannya ialah menerapkan kebijakan transportasi di Kota Malang.

\section{METODE}

Jenis penelitian yang digunakan adalah metode penelitian deskriptif dengan menggunakan pendekatan kualitatif. Lokasi penelitian ini di Terminal Landungsari Kota Malang. Dimana data yang didapatkan melalui studi pustaka hasil penelitian sebelumnya dan data yang diperoleh dari artikel berita dan dokumen-dokumen yang sesuai dengan tema penelitian. Ada dua jenis data yang digunakan peneliti yakni data primer dan data sekunder. Adapun data primer diperoleh peneliti melalui pengamatan yang dilakukan disekitar terminal Landungsari dan jalanan yang biasanya dilalui peneliti, yaitu Jl. Gajayana, Jl. Mayjen Pandjaitan, Jl. Veteran, J1. Dinoyo, Sumbersari, Jl. Tlogomas, Jl. Galunggung, dll. Sedangkan data sekunder adalah data yang diperoleh peneliti dari dokumen-dokumen dari Pemerintah Kota Malang atau Dinas Perhubungan Kota Malang, studi pustaka melalui karya ilmiah atau jurnal penelitian sebelumnya, dan artikel berita seperti Malangpos. Teknik pengumpulan data dengan menggunakan teknik observasi atau pengamatan dan dokumen. Observasi dilakukan pada tempat-tempat yang sering dilewati peneliti saat menuju kampus ataupun berpergian jauh. Disamping itu dokumentasi diperoleh peneliti dari karya yang telah ada sebelumnya dan artikel yang membahas mengenai halhal yang berkaitan dengan judul serta pembahasan dalam penelitian ini.

\section{HASIL DAN PEMBAHASAN}

Dari tahun ke tahun kemacetan menjadi permasalahan yang tidak bisa dihindari oleh kota besar seperti Kota Malang. Dimana perkembangan suatu kota juga dipengaruhi oleh bertambahnya aktivitas dan kebutuhan masyarakat. Hal ini didukung hasil penelitian yang dilakukan oleh Inrix yang memperlihatkan bahwa menurut Traffic Score Board 2017, Kota Malang berada diposisi ketiga penyandang kota termacet di Indonesia setelah Jakarta dan Bandung. Permasalahan kemacetan yang dialami Kota Malang ini tentu saja juga dipengaruhi oleh kondisi jalan yang tidak mengalami banyak perubahan sejak 10 tahun yang lalu. Sedangkan jumlah penduduk yang kian bertambah per tahunnya entah itu para pelajar atau mahasiswa luar kota yang datang untuk belajar di Kota Malang, pendatang yang datang untuk bekerja dan mengadu nasib, dan penduduk dari desa atau luar kota yang tinggal lalu menetap di Kota Malang. Selain itu, hal ini juga diperparah dengan keadaan transportasi umum yang sebagian dikatakan tidak cukup layak. 
Melihat kenyataan yang seperti ini tidak heran, banyak masyarakat Kota Malang yang lebih memilih menggunakan kendaraan pribadi atau ojek online sebagai moda transportasi. Angkot atau biasa yang disebut mikrolet sendiri sudah beroperasi di Kota Malang sejak tahun 1980-an, dimana pada saat itu angkot ini telah menjadi transportasi andalan bagi masyarakat yang ingin berpergian dari tempat satu ke tempat lainnya. Meskipun sekarang ini jumlah angkot tidak sebanyak dulu, karena mayoritas masyarakat memiliki kendaraan pribadi tidak menutup kemungkinan tingkat kemacetan di Kota Malang mengalami peningkatan setiap tahunnya.

Selain itu, angkot juga menjadi salah satu penyebab kemacetan karena seringnya pengemudi yang menyetir dan berhenti sembarangan sehingga menyebabkan kemacetan disekitarnya. Seakan menjadi kebiasaan yang sulit diubah meskipun pemerintah telah mengeluarkan kebijakan yang tertuang dalam Perda No 5 Tahun 2011 tentang Penyelenggaraan Angkutan Orang Di Jalan Dengan Kendaraan Bermotor Umum yaitu Pasal 22 yang salah satu ayatnya berbunyi bahwa menaikkan dan menurunkan penumpang harus sesuai tata cara, yakni di terminal sejak awal pemberangkatan, persinggahan, sampai tujuan dan tempat lain yang ditentukan. Akan tetapi hal tersebut tidak sejalan dengan kenyataan yang terjadi melihat banyaknya sopir angkot yang mencari penumpang dengan berhenti dipinggiran jalan raya seperti yang sering kita temui diantaranya di depan Stasiun Kota Baru, di depan terminal Landungsari, di depan pusat perbelanjaan, dll. Disamping itu banyaknya pengemudi atau sopir yang suka menaikkan dan menurunkan penumpang di jalanan yang cukup ramai dan sempit secara sembarangan tanpa melihat kendaraan lain yang berada disekelilingnya juga dinilai cukup berbahaya dan dapat menimbulkan kecelakaan lalu lintas. Pengemudi angkot juga terkesan semaunya dalam mengemudikan kendaraannya serta berpotensi membahayakan penumpang dan kendaraan lain.

Selain itu, permasalahan kemacetan yang terjadi di Kota Malang ini juga disebabkan oleh kurangnya sarana dan prasarana yang mendukung. Seperti halte yang cukup jarang dijumpai karena berada di area-area tertentu. Kemudian sempitnya jalan raya yang ada sangat tidak sesuai dengan jumlah kendaraan yang melewatinya setiap hari sehingga menimbulkan kemacetan pada jamjam tertentu dan juga tidak adanya trotoar di pinggiran jalan yang menyebabkan banyak orang yang kesulitan untuk berjalan kaki dengan aman. Oleh karena itu, pemerintah Kota Malang perlu membuat kebijakan yang secara jelas dapat diterapkan secara tegas untuk menekan kemacetan dan penyediaan serta perbaikan sarana transportasi umum khususnya angkot ongkosnya yang terbilang hemat dan mengingat jumlah penggunanya masih banyak meskipun tidak sebanyak dulu perlu menjadi perhatian pemerintah. Apalagi Kota Malang memiliki segudang Perguruan Tinggi bergengsi sehingga solusi dan upaya yang dilakukan pemerintah Kota Malang saat ini tentu akan berdampak pada perkembangan kota pada tahun-tahun selanjutnya. Mengingat jumlah penduduk Kota Malang yang terus bertambah, dimana pada tahun 2019 data BPS malang kota.bps.go.id menunjukkan bahwa jumlah penduduk Kota Malang telah mencapai 927.195 jiwa.

Maka pemerintah perlu membuat suatu kebijakan terhadap angkot di Kota Malang dengan merevitalisasi operasional atau penyediaan jasa angkutan umum yang berbasis aplikasi atau daring, ini bertujuan untuk memberikan kemudahan dan keuntungan pada supir angkot. Dimana supir angkot tidak harus menunggu penumpang di terminal atau ditempat-tempat pemberhentian lain yang tidak seharusnya. Kemudian untuk mengurangi kemacetan pemerintah Kota Malang juga beberapa kali berupaya dengan mulai menerapkan aturan baru dalam hal parkir. Disamping itu pemerintah Kota Malang juga beberapa kali membuat rekayasa lalu lintas pada jalan-jalan tertentu yang cukup ramai dilalui kendaraan umum maupun pribadi sebagai upaya untuk menanggulangi kemacetan. Selain itu, upaya yang telah dilakukan oleh pemerintah lainnya juga telah membuat kebijakan lalu lintas untuk mengurangi kemacetan, seperti yang kita tau bahwa sudah diberlakukannya sejak tanggal 6 November 2013 mengenai sistem jalur satu arah di kawasan lingkar UB yang ternyata dalam 
penerapannya sudah berjalan lancar dan dapat mengurai kemacetan yang ada.

Titik kemacetan yang terjadi saat ini berada di Jl. Soekarno-Hatta (Soehat), J1. Mayjen Panjaitan dan di Jl. MT Haryono. oleh karena tu Walikota Malang telah merancang adanya pelebaran di sejumblah titik, terutama di area tikungan atau pertigaan dan jika memungkinkan akan menggeser pagar pembatas perguruan tinggi yang beringgungan dengan jalan raya umum, seperti yang ada di area Universitas Brawijaya dan POLTEK Malang agar jalan lebih lebar. Oleh karena itu pemerintah Kota malang dan Pimpinan-Pimpinan kampus berembk untuk mencari solusi yang terbaik untuk mengurangi kemcetan disekiar area universitas. Program lain yang bertujuan untuk membantu kemacetan ini ialah, Walikoa Malang telah berenana untuk mengatur ulang ja, masuk dan pulang kerja kantor, khususnya bagi ASN, mahasiswa dan sejumblah sekolah di Kota Malang (berita malangkota.go.id).

Kebijakan yang sudah diterapkan oleh pemerintah untuk mengurangi kemacetan di Kota Malang ternyata hanya berpengaruh dibeberapa jalur tertentu saja. Oleh karena itu Dinas perhubungan (dishub) Kota Malang telah menerepkan kebijakan baru dalam parkir. Kebijakan ini berlaku Khusus di kawasan Alunalun Kota Malang, kawasan Pecinan, hingga pasar besar telah diberlakukan parkir miring atau serong ( 30 hingga 50 derajat) mulai tahun 2015. Selain itu Dishub juga telah memilah-milah ruang parkir untuk sepeda motor dan mobil dengan memasang plang khusus untuk kendaraan roda dua dan kendaraan roda empat agar terlihat lebih rapi dan nyaman. Untuk mereka yang mlanggar akan diberikan sanksi tersendiri dari dishub Kota Malang. dengan adanya kebijakan posisi parkir tersebut, lebar kendaraan yang dilewati akan lebih lebar kurang lebih satu meter, dan arus lalu lintas akan lebih lancar karena keluar masuknya kendaraan tidak akan menganggu kendaraan lain yang melintas dan tidak akan mengakibatkan macet. Kebijakan ini berfokus pada kawasan pasar besar yang telah dijadikan satu keaeh timur sehingga kemacetan diarah pasar besar bisa berkurang.
Namun beberapa kebijakan yang sudah diterapkan tidak mengubah kemacetan yang ada di Kota Malang. Faktor utama penyebab kemacetan di Kota Malang ini ialah kapasitas jalan raya yang tidak seimbang dengan peningkatan jumlah kendaraan bermotor. Kendaraan pribadi yang semakin meningkat dan angkutan umum (Angkot) yang berhenti mendadak ini menjadi fokus utama dalam menangani kemacetan hingga saat ini. Mengingat bahwa sistem transportasi ini membawa dampak luas terhadap kehidupan masyarakat, maka sebaiknya pemerintah harus memikirkan solusi tegas dalam menyikapi transportasi pubik khususnya Angkutan umum (Angkot). Adanya kemacetan dikota Malang ini tidak hanya karena meningkatnya transpotasi Pribadi yang semakin meningkat tetapi angkutan umum (angkot) yang sering berhenti di sembarang tempat, sopir yang ugal-ugalan, menarik ongkos diluar ketentuan, dan waktu pelayanan yang tidak jelas ini merupakan tantangan Pemerintah Kota Malang yang harus diselesaikan. Oleh karena beberapa angkutan umum (angkot) saat ini terlihat tidak banyak penumpang dan lebih memilih transpotasi berbasi online atau daring. Tetapi dengan munculnya transportasi online ini malah menambah kemacetan di Kota Malang. transportasi berbasis aplikasi atau daring ini berada pada waktu yag kurang tepa, sehingga mereka menjadi kambing hitam dalam merebut uang setoran dan mengakibatkan konflik antara angkutan umum (angkot) dengan transportasi berbasis aplikasi, hal tersebut justru menghasilkan konflik antara mereka berdua dan berdampak pada kemacetan Kota Malang.

Baru-baru ini untuk mengurangi kemacetan dan kerusuhan angkutan umum (angkot) dalam berkendara, Walikota Malang telah menyediakan angkutan berbasis aplikasi atau daring. Walikota Malang telah melaksankaan penandatanganan Memorandum of Undertanding (MoU) dengan PT Teknologi oleh rancang Nusantara (TRON) sebagai penyedia aplikasi angkot online. Penerapan uji coba ini rencananya akan dilaksankaan di bulan April 2020 dan akan dilakukan secara bertahap. Tetapi karena keadaan kurang mendukung hal tersebut masih menjadi wacana hingga saat ini. 


\section{SIMPULAN}

Kemacetan di Kota Malang disebabkan oleh meningkatnya kendaraan pribadi roda dua maupun roda empat, dan angkutan umum (angkot) yang sering berhenti mendadak untuk menaikkan penumpang. Beberapa kebijakan yang telah diterapkan oleh pemerintah untuk menanggulangi kemacetan ini seperti mengenai sistem jalur satu arah di kawasan lingkar UB yang ternyata dalam penerapannya sudah berjalan lancar, parkir miring atau serong di kawasan Pasar Besar Kota Malang. Kedua kebijakan tersebut berjalan dengan lancar, namun hanya mengurangi sedikit angka kemacetan. Sebagai solusi Walikota Malang telah merancang kebijakan yang berfokus kepada angkutan umum (angkot) yang akan berbasis aplikasi atau daring yang sebenarnya dilaksanakan ujicoba pada bulan April 2020 ini, tetapi kebijakan ini masih belum terelisasikan karena terhambat oleh situasi saat ini.

\section{DAFTAR RUJUKAN}

Asmawi, Awing, D.F. Sjoraida, R.K. Anwar. 2017. Masalah dan Dinamika Kebijakan Publik tentang Transportasi. CosmoGov:
Jurnal Ilmu Pemerintahan, 3 (2), 205218.

Arivin, M. S. 2018. Implementasi Kebijakan Pemerintah Kota Malang dalam perbaikan transportasi publik untuk mengurangi kemacetan di Kota Malang.

Ekawati, N. N. 2014. Kajian Dampak Pengembangan Pembangunan Kota Malang Terhadap Kemacetan Lalu Lintas (Studi pada Dinas Perhubungan Kota Malang). Jurnal Administrasi Publik, 2(1), 129-133.

Mediansyah, Achmad Risa, 2017. Jaringan Kebijakan Publik Implementasi Kebijakan Transportasi di Kota Makassar. Jurnal Analisis dan Kebijakan Publik, 3 (1), 14-22

Putri,E.H. 2013. Evaluasi Kebijakan Peremajaan Angkutan Kota dalam Upaya Peningkatan Pelayanan Publik (Studi pada Dinas Perhubungan Kota Malang). Jurnal Administrasi Publik, 1 (3), 87-93.

Yunas, N. S. 2017. Kebijakan Revitalisasi Sistem Transportasi Publik sebagai Langkah Antisipatif Kemacetan Total di Kota Malang. CosmoGov: Jurnal Ilmu Pemerintahan, 3 (1), 116-126. 